\title{
EPSL
}

Earth and Planetary Science Letters 127 (1994) 55-66

\section{Neodymium isotopic variations in North Pacific modern silicate sediment and the insignificance of detrital REE contributions to seawater}

\author{
Charles E. Jones, Alex N. Halliday, David K. Rea, Robert M. Owen \\ Department of Geological Sciences, University of Michigan, Ann Arbor, MI 48109-1063, USA
}

Received 18 March 1994; accepted after revision 9 August 1994

\begin{abstract}
The neodymium isotopic composition of the silicate fraction of Holocene pelagic sediments from the North Pacific define two provinces: a central North Pacific province characterized by unradiogenic and remarkably homogeneous $\epsilon_{\mathrm{Nd}}(-10.2 \pm 0.5)$ and a narrow circum-Pacific marginal province characterized by more radiogenic and variable $\epsilon_{\mathrm{Nd}}(-4.2 \pm 3.8)$. The silicate fraction in the central North Pacific is exclusively eolian; based on prevailing wind patterns, meteorological data, and neodymium isotopic data, the only significant sediment source is Chinese loess. Leaching experiments on Chinese loess confirm that leachable $\mathrm{Nd}$ is isotopically indistinguishable from bulk and residual silicate Nd. Silicates in the circum-North Pacific marginal province comprise eolian loess, volcanic ash, and hemipelagic sediments derived from volcanic arcs. A compilation of Pacific seawater and $\mathrm{Mn}$ nodule $\epsilon_{\mathrm{Nd}}$ data shows no clear spatial variation except for a general decrease from surface to deep waters from -3 to -4 and slightly lower $\epsilon_{\mathrm{Nd}}$ in bottom waters along the western North Pacific due to the incursion of Antarctic Bottom Water. The relative homogeneity of bottom water $\epsilon_{\mathrm{Nd}}$, which contrasts sharply with the distinctive variation in sediment $\epsilon_{\mathrm{Nd}}$, plus the large difference between the average $\epsilon_{\mathrm{Nd}}$ of bottom waters and the central North Pacific eolian silicates $(-4$ vs. -10$)$, suggests that any contribution of REE to seawater from eolian materials is insignificant. Furthermore, leaching of REE from eolian particles as they sink though the water column must be insignificant because $\mathrm{Nd}$ in shallow waters is more radiogenic than $\mathrm{Nd}$ in deeper waters. That there is no contrast in the Nd isotopic composition of bottom waters that overlie the central and marginal sediment provinces suggests that the ash and hemipelagic sediments derived from Pacific rim volcanic arcs also contribute minimal REE to seawater. The elimination of eolian, ash, and hemipelagic sediments leaves only near-shore riverine particulates as a possibly significant particulate source of REE to seawater.
\end{abstract}

\section{Introduction}

The only well-documented source of rare earth elements (REEs) to the oceans is river water [1-3]. Hydrothermal vents have low concentrations of REE [4,5] and in any case efficient scavenging by $\mathrm{Fe}-\mathrm{Mn}$ oxides in the vent plumes reduces the potential hydrothermal REE fluxes to the point where hydrothermal activity may even represent a net sink for the REEs [6-8]. A proposed source of REE that requires further evaluation is marine detrital sediments and volcanic ash. It has been proposed, for example, that eolian detrital sediments and volcanic ash contribute enough REE to seawater to determine the $\mathrm{Nd}$ isotopic composition of large areas of the 
Atlantic and Pacific oceans [9]. Such a large detrital flux of REE has major implications for REE cycling in seawater.

The world's oceans contain a total $4.1 \times 10^{10}$ moles of $\mathrm{Nd}$; a river flux of roughly $10^{7} \mathrm{~mol} / \mathrm{yr}$ $\mathrm{Nd}$ yields a residence time of 4100 years $[1,10]$. Oceanic distributions of REE, in particular their covariance with silica and systematic increase in deep water concentrations and inter-REE fractionation as a function of increasing water mass age (Pacific $>$ Indian $>$ Atlantic), similarly suggest a residence time of several thousand years $[10,11]$. However, the large $\mathrm{Nd}$ isotopic contrasts between the oceans seem to imply shorter residence times of about the mixing time of the oceans, roughly 1000 years [10], and thus a significantly larger flux of $\mathrm{Nd}$ to seawater. One proposed solution to this problem [10] is to increase the flux of $\mathrm{Nd}$ (and the other REE) from the surface to deep oceans by a mechanism of rapid reversible sorption-desorption reactions on settling particles that is analogous to a process inferred from Th isotope studies [12]. The model of Bertram and Elderfield [10] assumes that the only source of REE to the oceans is river water. The addition of large fluxes of REE either from eolian detrital silicates settling in the water column or deposited on the seafloor, as proposed by Albarède and Goldstein [9], would therefore strongly modify the calculated importance of particle-seawater REE exchange, possibly even eliminating the need for such a mechanism.

The importance of a flux of REEs derived from the leaching or breakdown of detrital minerals brought to the oceans by eolian or riverine processes has proved difficult to evaluate. The potential importance to the North Pacific of just the eolian detrital $\mathrm{Nd}$ contribution is illustrated by the fact that the eolian flux would equal the dissolved riverine flux even if only $1.5 \%$ of the total eolian REE actually goes into solution [13] (Table 1). Given this obvious potential, the possibility of a detrital source of dissolved REE has often been discussed, but without firm conclusions regarding its significance. For example, although early work on the REE budget for the Mediterranean suggested a significant flux of detrital $\mathrm{Nd}[14,15]$, subsequent measurements led to
Table 1

Nd budget for the North Pacific (in $10^{6} \mathrm{~mol} / \mathrm{yr}$ )

\begin{tabular}{lcccc}
\hline & Global & Pacific & North Pacific & Ref \\
\hline Dissolved Riverine Nd & 10 & 3 & 2 & {$[1,2]$} \\
T(tal Dust Nd & 220 & 130 & 120 & {$[50]$} \\
1.5\% Dissolution of Dust Nd & 7 & 4 & 4 & {$[13]$} \\
Suspended River Nd & 1700 & 800 & 500 & {$[51,52]$} \\
\hline
\end{tabular}

The total flux of dust to the oceans may be roughly a factor of 5 lower $[23,50]$; on the other hand, the average percentage of total REE dissolving from eolian particulates may be 2 to 10 times as great $[3,13]$. The modern riverine suspended load is halved to correct for human activities [51]; Pacific suspended fluxes are estimated from the map of Milliman and Meade; much of the suspended load is not transported beyond estuaries and deltas into the open ocean [52].

the conclusion that the budget discrepancy is more likely explained by an influx of metal-rich seawater from the Spanish shelf [16]. The presence of greatly elevated REE concentrations and a negative Eu anomaly in a sample of Atlantic surface water downwind of the Sahara Desert suggests a substantial flux of REE from eolian material [17], as does a water column profile in the northwest Pacific showing remarkably unradiogenic $\mathrm{Nd}$ isotopic ratios in shallower waters [18]. However, these observations still leave the overall importance of an eolian flux unclear. At present the most striking line of evidence in favor of a significant detrital source is a general correspondence in the spatial patterns of the ${ }^{143} \mathrm{Nd} /{ }^{144} \mathrm{Nd}$ ratio between core-top sediments and $\mathrm{Mn}$ nodules in several large areas of the Atlantic and Pacific [9]. This correspondence is taken to support the idea that the flux of $\mathrm{Nd}$ derived from detrital minerals and/or their oxide coatings either in the water column $[17,19,20]$ or on the sea floor [21] is sufficient to control the regional patterns of ${ }^{143} \mathrm{Nd} /{ }^{144} \mathrm{Nd}$ in seawater.

\section{Samples and methods}

We have determined the ${ }^{143} \mathrm{Nd} /{ }^{144} \mathrm{Nd}$ ratio of 16 modern and Holocene detrital silicate samples from the North Pacific in order to examine more closely the relationship between sediment and seawater ${ }^{143} \mathrm{Nd} /{ }^{144} \mathrm{Nd}$. When combined with data for 9 similarly collected and processed detrital silicate samples in Nakai et al. [22], of which 6 are 
(a)

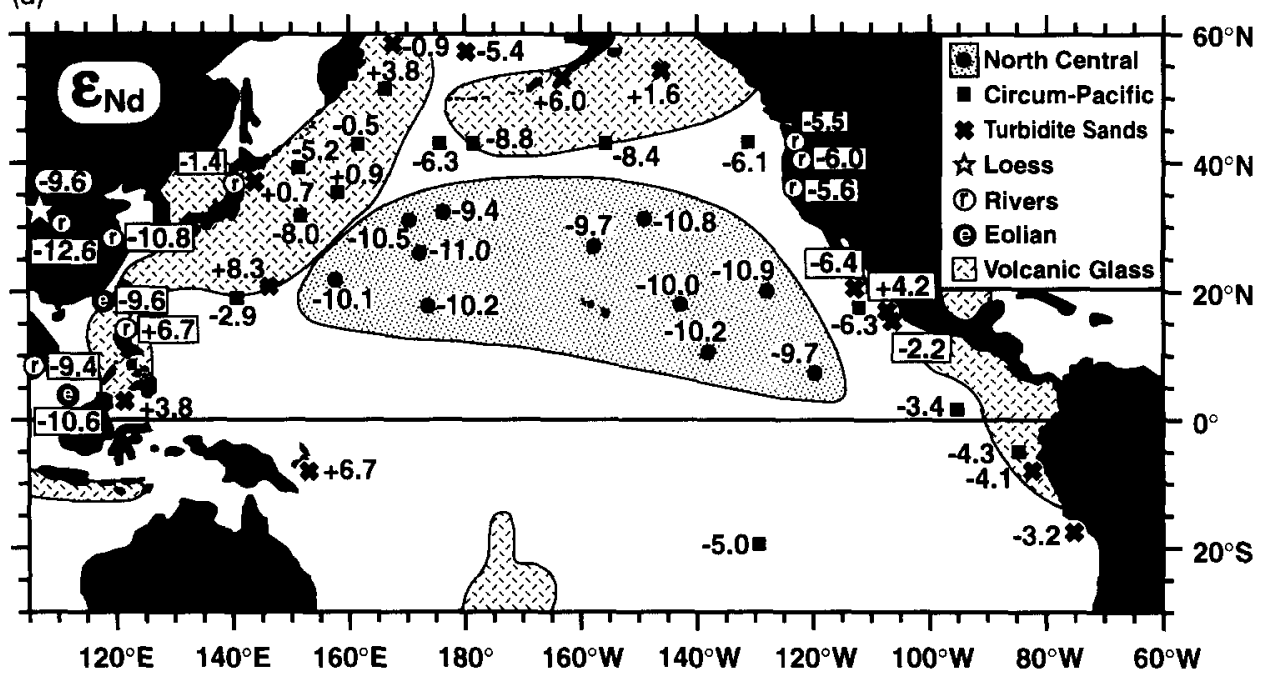

(b)

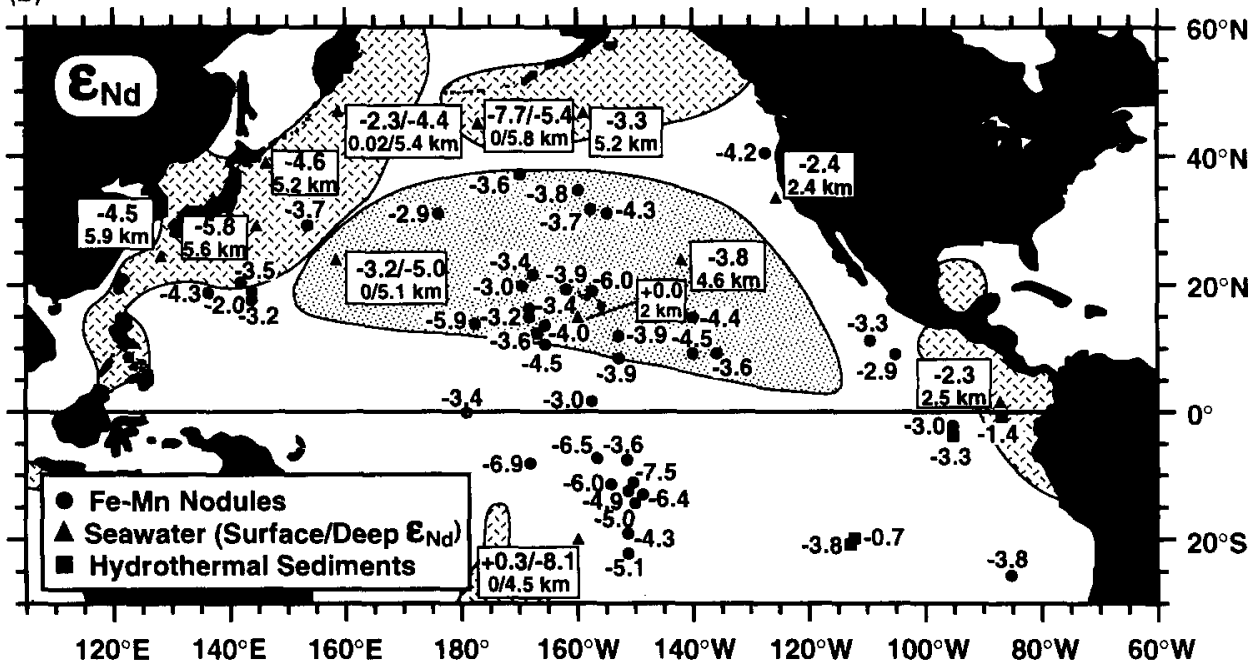

Fig. 1. (a) Map of the Pacific Ocean showing the location and $\epsilon_{\mathrm{Nd}}$ of Holocene and late Quaternary [22] detrital silicate samples. Stippled area represents the central North Pacific province characterized by $\epsilon_{\mathrm{Nd}}=-10.2 \pm 0.5$; hachured areas represent regions of the sea floor containing abundant visible volcanic ash [46]. Eolian and riverine $\epsilon_{\mathrm{Nd}}$ data [34,36] provide an indication of the $\epsilon_{\mathrm{Nd}}$ of sediments up-wind from the central North Pacific while data from turbidite sands [29] yield information on materials eroding from Pacific rim island arcs. There is no $\epsilon_{\mathrm{Nd}}$ evidence for a significant flux of eolian material to the eastern Pacific from western North America [31]. (b) Map of the Pacific Ocean showing the location and $\epsilon_{\mathrm{Nd}}$ of seawater and Mn nodule samples. The stippled and hach $i:$ id areas are from Fig. 1a. Some seawater samples show surface and bottom water $\epsilon_{\mathrm{Nd}}$ and sample depths separated by a backslash. Except for the influence of AABW on Mn crusts in the central South Pacific and on bottom water samples in the western North Pacific, there appears to be no systematic variations in seawater or Mn nodule $\epsilon_{\mathrm{Nd}}$ in the Pacific Ocean. Specifically, there is no contrast between the central North Pacific underlain by eolian Chinese loess and the marginal regions underlain by volcanic ash and young continental detritus. Moreover, there is no evidence for a minimum in $\mathrm{e}_{\mathrm{Nd}}$ centered on the -6 datum east of Hawaii [9]. 
less than 32 ka old and all are Quaternary in age, these data allow an evaluation of the importance of eolian and hemipelagic detrital inputs in controlling the $\mathrm{Nd}$ isotopic composition of modern Pacific seawater. Although most samples in this study and in Nakai et al. [22] are located far enough away from land (Fig. 1a) to reflect only eolian transport of the silicate fraction [23], those samples located within $500-1000 \mathrm{~km}$ of land may contain a hemipelagic component. In contrast to most previous $\mathrm{Nd}$ isotopic analyses of Pacific pelagic sediments [24-26], in this study all biogenic and hydrogenous (Fe-Mn oxides) phases are removed from each sample. This extraction procedure [27] involves a sequential treatment using acetic acid, sodium bicarbonate or sodium hydroxide, and sodium dithionite to remove carbonate, biogenic silica, and $\mathrm{Fe}-\mathrm{Mn}$ oxides. This treatment may dissolve sub-micron, neoformational smectites, but does not appear to affect detrital silicate minerals or volcanic ash. The mild sodium bicarbonate treatment may not remove all biogenic silica from silica-rich samples, but any remaining silica is unlikely to host enough seawater $\mathrm{Nd}$ to bias the silicate results presented below. In addition, $1 \mathrm{M} \mathrm{HCl}$ and water rinses (using ultra-pure reagents) are applied to remove any contamination introduced by the extraction reagents listed above. The procedures for sample dissolution, $\mathrm{Nd}$ separation, and isotopic analyses are presented elsewhere $[8,22,28]$. Hereafter ${ }^{143} \mathrm{Nd} /{ }^{144} \mathrm{Nd}$ ratios are expressed as deviations in parts per 10,000 of the sample ${ }^{143} \mathrm{Nd} /{ }^{144} \mathrm{Nd}$ from the bulk earth value of 0.512638 .

In addition to the Pacific surface sediments, we have analyzed leachate and residue fractions for 3 Chinese loess samples. Chinese loess is a dominant source of eolian silicates for the North Pacific, and the $\mathrm{Nd}$ isotopic analysis of leachates provides an indication of the $\mathrm{Nd}$ most likely to be leached from loess in seawater. The leaching procedure first uses $10 \%$ acetic acid to dissolve the carbonate fraction (up to $\sim 30 \mathrm{wt} \%$ of loess); some dissolution of the iron oxides is also likely. 1 $M \mathrm{HCl}$ is then used to leach the iron oxides, although a contribution from the silicate fraction is also likely. After each step the sample is rinsed once in the acid used for leaching and three times
Table 2

Data for sediment samples analyzed in this study

\begin{tabular}{|c|c|c|c|c|c|c|}
\hline Core & Latitude & Longitude & Depth (m) & Interval & $143 \mathrm{Nd} / 144 \mathrm{Nd} \pm 2 \sigma$ & $\varepsilon_{N_{0}}+2 \sigma$ \\
\hline \multicolumn{7}{|c|}{ North Pacific Central Province } \\
\hline RP2OC72-04GC & $24^{\circ} 50^{\prime} \mathrm{N}$ & $156^{\circ} 12 \mathrm{E}$ & 5262 & $0-3 \mathrm{~cm}$ & $0.512120 \pm 11$ & $-10.1 \pm 0.2$ \\
\hline KK 75-PCOD 13 & $33^{\circ} 22^{\prime} \mathrm{N}$ & $169^{\circ} 05 \mathrm{E}$ & 5736 & $0-4 \mathrm{~cm}$ & $0.512101 \pm 9$ & $-10.5 \pm 0.2$ \\
\hline $\mathrm{RP} 2 \mathrm{OC} 72-11 \mathrm{GC}$ & $28^{\circ} 07 \mathrm{~N}$ & $170^{\circ} 57^{\prime} \mathrm{E}$ & 5983 & $0-3 \mathrm{~cm}$ & $0.512076 \pm 17$ & $-11.0 \pm 0.3$ \\
\hline Y74-3-69MG4 & $33^{\circ} 26^{\prime} \mathrm{N}$ & $151^{\circ} 01 \mathrm{~W}$ & 5524 & $0-3 \mathrm{~cm}$ & $0.512086 \pm 22$ & $-10.8 \pm 0.4$ \\
\hline $\mathrm{Y} 74-2-40 \mathrm{GC}$ & $20^{\circ} 07 \mathrm{~N}$ & $145^{\circ} 35 \mathrm{~W}$ & 5490 & $0-3 \mathrm{~cm}$ & $0.512128 \pm 7$ & $-10.0+0.1$ \\
\hline SCAN-10PG & $13^{\circ} 52^{\prime} \mathrm{N}$ & $140^{\circ} 10 \mathrm{~W}$ & 4864 & $5-7 \mathrm{~cm}$ & $0.512113 \pm 7$ & $.10 .2 \pm 0.1$ \\
\hline Y74-2-35MG3 & $22^{\circ} 35 \mathrm{~N}$ & $129^{\circ} 20^{\mathrm{W}}$ & 4647 & $0-3 \mathrm{~cm}$ & $0.512079 \pm 19$ & $-10.9 \pm 0.4$ \\
\hline TT34-07PC & $09^{\circ} 58^{\prime} \mathrm{N}$ & $122^{\circ} 42 \mathrm{~W}$ & 4586 & $2-4 \mathrm{~cm}$ & $0.512141 \pm 8$ & $-9.7 \pm 0.2$ \\
\hline \multicolumn{7}{|c|}{ North Pacific Margin Province } \\
\hline RP2OC72-01GC & $21^{\circ} 18^{\prime} \mathrm{N}$ & $139^{\circ} 59^{\prime} \mathrm{E}$ & 4699 & $0-3 \mathrm{~cm}$ & $0.512490 \pm 11$ & $-2.9 \pm 0.2$ \\
\hline TT49-16AC & $34^{\circ} 56^{\prime} \mathrm{N}$ & $150^{\circ}(0) \mathrm{E}$ & 6035 & $0-3 \mathrm{~cm}$ & $0.512227 \pm 11$ & $-8.0 \pm(0.2$ \\
\hline TT49. I8AC & $41^{\circ} 01 \mathrm{~N}$ & $150^{\circ} 01 \mathrm{E}$ & 5185 & () $-3 \mathrm{~cm}$ & $0.512372 \pm 10$ & $-5.2 \pm 0.2$ \\
\hline Vinugradov19-17GG & $53^{\circ} 42^{\prime} \mathrm{N}$ & $\left.165^{\circ}\right)(1 \mathrm{E}$ & 3960 & $4-7 \mathrm{~cm}$ & $0.512831 \pm 25$ & $+3.8 \pm 0.5$ \\
\hline Y7()-1-23MG & $45^{\circ} 19^{\prime} \mathrm{N}$ & $174^{\circ} 17 \mathrm{E}$ & 7155 & (1) $-3 \mathrm{~cm}$ & $0.512313 \pm 9$ & $-6.3 \pm 0.2$ \\
\hline Y70-1-21MG1A & $45^{\circ} 06 \mathrm{~N}$ & $180^{\circ}(\mathrm{K})^{\circ}$ & 5635 & (1) $3 \mathrm{~cm}$ & $0.512185 \pm 13$ & $.8 .8 \pm 0.3$ \\
\hline Y70-1-12MG 1 & $45^{\circ} 04^{\prime} \mathrm{N}$ & $157^{\circ} 25 \mathrm{~W}$ & 5372 & $0.3 \mathrm{~cm}$ & $0.512207 \pm 11$ & $-8.4 \pm 0.2$ \\
\hline Y74-2-3]MG2 & $20^{\circ} 15^{\prime} \mathrm{N}$ & $113^{\circ} 57 \mathrm{~W}$ & 3590 & 0) $3 \mathrm{~cm}$ & $0.512315 \pm 7$ & $-6.3 \pm 0.1$ \\
\hline
\end{tabular}

All analyses performed on a VG Sector multicollector thermal ionization mass spectrometer in multidynamic analysis mode. Data normalized to ${ }^{146} \mathrm{Nd} /{ }^{144} \mathrm{Nd}=0.7219$; La Jolla ${ }^{143} \mathrm{Nd} /{ }^{144} \mathrm{Nd}=0.511840 \pm 18 \quad(2$ S.D.; $n=30) ; \epsilon_{\mathrm{Nd}} \pm$ $\left\{\left({ }^{143} \mathrm{Nd} /{ }^{144} \mathrm{Nd}-0.512638\right) / 0.512638\right\} \times 10^{4}$.

* Standard errors refer to last significant digits of an individual analysis.

in water. Finally, we put the remaining residues through the extraction procedure described above and treat them similarly to the Pacific sediment samples.

\section{Results}

The location, depth in core, and isotopic data for each sample are presented in Table 2. There is a clear division of the data into a large central North Pacific province characterized by sediment with $\epsilon_{\mathrm{Nd}}=-10.2 \pm 0.5$ (mean \pm 1 S.D.) and a circum-Pacific province with more radiogenic but variable $\epsilon_{\mathrm{Nd}}=-4.2 \pm 3.8$ (Fig. 1a). Some previously published data for pelagic sediments from the central province [24-26] are significantly more radiogenic and variable $\left(\epsilon_{\mathrm{Nd}}=-6.1 \pm 1.6\right)$. This offset towards more radiogenic $\epsilon_{\mathrm{Nd}}$ and greater variability is probably due to the inclusion in previous works of variable amounts of hydrogenous $\mathrm{Fe}-\mathrm{Mn}$ oxides, which have REE concentrations roughly 10 times those of clay minerals and $\mathrm{Nd}$ derived from Pacific seawater $\left(\epsilon_{\mathrm{Nd}} \approx-4\right)$. Published data [29] on sediments in the marginal province are considerably more radiogenic $(+0.7$ \pm 4.8 ) than the data obtained in this study and in Nakai et al. [22]. This is probably because whereas 
Table 3

Data for leachates and residues of Chinese loess samples

\begin{tabular}{lccccccc}
\hline Sample & \multicolumn{2}{c}{$10 \%$ Acetic Leach } & \multicolumn{2}{c}{ 1 MHCl Leach } & \multicolumn{2}{c}{ Silicate Fraction } \\
& \multicolumn{1}{c}{$143 \mathrm{Nd} / 144 \mathrm{Nd}$} & $\varepsilon_{\mathrm{Nd}}$ & \multicolumn{1}{c}{$143 \mathrm{Nd} / 144 \mathrm{Nd}$} & $\varepsilon_{\mathrm{Nd}}$ & \multicolumn{1}{l}{$143 \mathrm{Nd} / 144 \mathrm{Nd}$} & $\varepsilon_{\mathrm{Nd}}$ \\
\hline Lanzhou & $0.512171 \pm 26$ & $-9.1 \pm 0.5$ & $0.512166 \pm 32$ & $-9.2 \pm 0.6$ & $0.512068 \pm 11$ & $-11.1 \pm 0.2$ \\
$\mathrm{H} 251$ & $0.512135 \pm 27$ & $-9.8 \pm 0.5$ & $0.512119 \pm 24$ & $-10.1 \pm 0.5$ & $0.512037 \pm 10$ & $-11.7 \pm 0.2$ \\
$\mathrm{H} 260$ & $0.512090 \pm 26$ & $-10.7 \pm 0.5$ & $0.512116 \pm 31$ & $-10.2 \pm 0.6$ & $0.512063 \pm 5$ & $-11.2 \pm 0.1$ \\
\hline
\end{tabular}

Lanzhou Loess [22]; H251, H260 samples are from a $10 \mathrm{~m}$ section of primary loess sampled at Haojiatai, China (northwest of Bejing).

the data of McLennan et al. [29] are based on turbidites that transport material directly from the island arc-dominated land masses surrounding the Pacific rim, the data presented here derive from eolian and hemipelagic materials that reflect a mixture of sediment and ash from the island arcs and loess from China.

The results of the leaching experiments are presented in Table 3. In all three cases the $\epsilon_{\mathrm{Nd}}$ of the acetic acid ( $\sim$ carbonate fraction) and hydrochloric acid ( $\sim \mathrm{Fe}$ oxide fraction) leaches are very similar to each other, ranging between -9.1 and -10.7 . The residues are slightly less radiogenic, ranging between -11.1 and -11.7 . These data suggest that although the 3 fractions are chemically quite distinctive, isotopically they are fairly homogeneous. There is no evidence for an easily dissolved, isotopically distinct phase in the loess that would host $\mathrm{Nd}$ that is as radiogenic as Pacific seawater $\left(\epsilon_{\mathrm{Nd}} \approx-4\right)$.

\section{Discussion}

Based on meteorological observations, the major source of dust for the North Pacific is thought to be Chinese loess transported by the westerlies [23,30-32]. These modern observations can be extended to the Holocene by comparing the $\epsilon_{\mathrm{Nd}}$ of the central North Pacific sediments, -10.2 , with the $\epsilon_{\mathrm{Nd}}$ of Chinese loess and the eolian and riverine particulates derived from the loess belts of southeast Asia. Three samples of Chinese loess yield an average $\epsilon_{\mathrm{Nd}}$ of $-9.9 \pm 0.3[22,33,34]$ and the Yellow, Yangtze, and Mekong rivers [34] draining the loess regions have particulate $\epsilon_{\mathrm{Nd}}$ values between -9.4 and -12.6 (Fig. 1a). Eolian mineral samples collected on ships sailing west of the southern Philippines and off southeastern China (Fig. 1a) give $\epsilon_{\mathrm{Nd}}$ of -10.6 and -9.6 , respectively [34]. Taken together, these data indicate that the Chinese loess is characterized by an $\epsilon_{\mathrm{Nd}}$ of about -10 . This is identical to the central North Pacific sediment $\epsilon_{\mathrm{Nd}}$, and distinctly different from all other riverine and eolian measurements around the Pacific rim (Fig. 1a), and thus the areal extent of the central North Pacific sediment province gives a clear indication of the importance of wind-blown Chinese loess across the entire central North Pacific.

The relatively radiogenic $\epsilon_{\mathrm{Nd}}$ of sediments from the narrow marginal province suggests significant contributions from ash and detritus derived from the volcanic arcs $\left(\epsilon_{\mathrm{Nd}}\right.$ generally greater than -4 ; Fig. 2c) and young continental crust that dominate the margins of the Pacific rim. Although there is a suggestion [31,35] that a minor amount of dust may be transported to the subtropical North Pacific from the deserts of southwestern North America, the Chinese loess $\left(\epsilon_{\mathrm{Nd}}=-10\right)$ seems to dominate any western North American component $\left(\epsilon_{\mathrm{Nd}} \approx-6[22,34,36]\right)$ over all but a very narrow strip in the eastern Pacific.

The eolian transport of loess to the ocean is expected to deliver 3 main components. Carbonate minerals can comprise up to $20-30 \%$ of Chinese loess, and the settling of the carbonate component below the lysocline should result in carbonate dissolution and the consequent release of REE to seawater. Fe oxide coatings of mineral grains in the loess may host a significant fraction of REE that may go into solution in seawater if the oxides exchange REE in the water column, or if they are reduced during the biological production of the fecal pellets that rapidly transport much of the detrital material to the seafloor, or if sediment pore waters expel the REEs released during reductive dissolution of $\mathrm{Fe}$ oxides during sediment burial. The silicate component of the loess is certainly resistant to bulk dissolution, but as indicated in Table 1 , only a small fraction need "dissolve" (either true dissolution, recrystallization, or leaching of REE from interlayer sites and lattice dislocations) to yield a substantial flux of $\mathrm{REE}$ to seawater. The leachate/residue data in 
Table 3 indicate that all three components of the loess are isotopically very similar and thus that the dissolution of any of the three will have the same isotopic impact on seawater. Similarly, it seems highly unlikely that there is an isotopic contrast between the silicate and exchangeable components in volcanogenic detritus. Thus, for both the loess and young crustal source materials, the map in Fig. 1a should represent a good approximation of the regional isotopic variations in

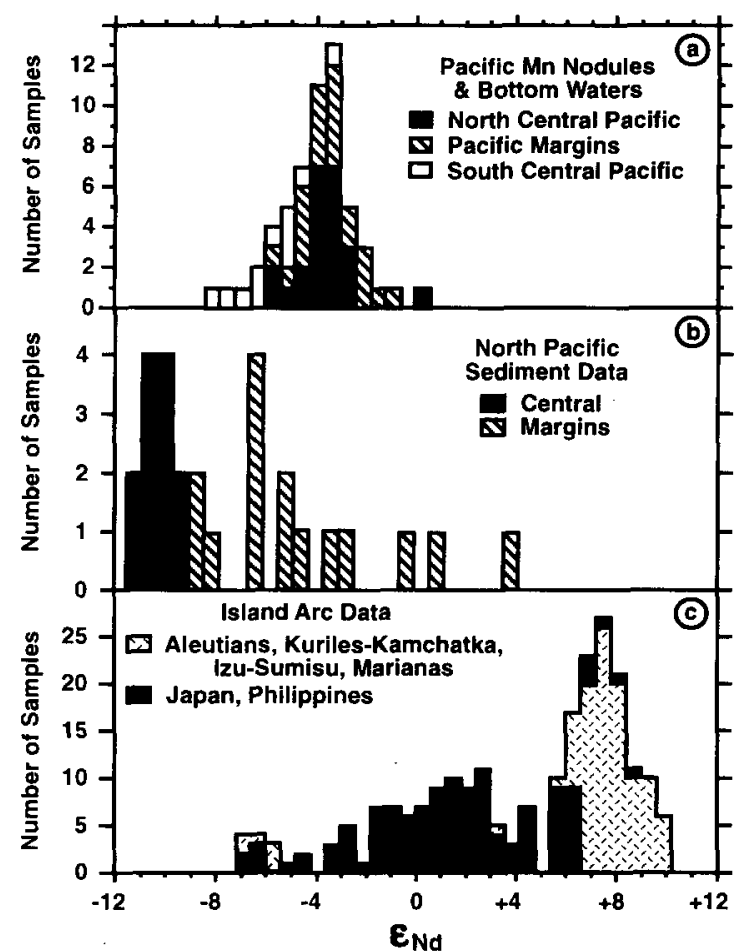

Fig. 2. Histograms comparing the $\epsilon_{\mathrm{Nd}}$ values of Pacific bottom waters (represented by seawater samples, Mn nodules, and $\mathrm{Mn}$ encrustations), of the central and marginal sediment data presented in this study and in Nakai et al. [22], and of island arc volcanic rock data compiled from the literature (including mostly late Cenozoic basaltic andesites and andesites). The sediment data (b) represent the likely isotopic composition of potential detrital Nd inputs to Pacific seawater (a). The island arc data (c) represent the likely composition of $\mathrm{Nd}$ derived from volcanic ashes observed on the seafloor [46]. Although some mixture of central province sediment and ash $\mathrm{Nd}$ could explain the $\epsilon_{\mathrm{Nd}}$ of Pacific seawater (a), the fact that there is no contrast in the $\epsilon_{\mathrm{Nd}}$ of the slowly circulating Pacific bottom waters overlying these isotopically distinctive sediment types strongly suggests that any detrital or ash REE inputs are minimal. the potential dissolved Nd fluxes related to eolian and hemipelagic detrital silicate inputs to the North Pacific.

To assess the potential impact of these detrital REE fluxes on seawater, the vertical and horizontal variations in Pacific seawater $\epsilon_{\mathrm{Nd}}$ need to be established. The oceanic residence time of $\mathrm{Nd}$ is sufficiently short that major isotopic contrasts develop between oceans and smaller contrasts are found within oceans, but long enough that the major water masses within a given ocean retain distinctive $\epsilon_{\mathrm{Nd}}$ values reflecting their source inputs. For example, the influence of the North Atlantic Deep Water, which originates with $\epsilon_{\mathrm{Nd}}$ $\approx-13.5$, and the Antarctic Intermediate and Bottom Waters, which start with $\epsilon_{\mathrm{Nd}} \approx-8$, is clearly seen in several water column profiles in the South Atlantic between $30^{\circ}$ and $50^{\circ} \mathrm{S}$ [11]. In the Pacific Ocean the main source of deep water is the Southern Ocean. The Antarctic deep water masses move northwards with the flow focused along the deepest parts of the western Pacific. The few $\epsilon_{\mathrm{Nd}}$ data obtained directly from North Pacific seawater [18,37-39] reflect this flow: bottom waters tend to have lower $\epsilon_{\mathrm{Nd}}(<-4.5)$ in the western North Pacific than in the central and eastern Pacific ( $>-4.0$; Fig. 1b), as well as significantly lower $\epsilon_{\mathrm{Nd}}$ than would be predicted on the basis of the roughly linear decrease in $\epsilon_{\mathrm{Nd}}$ with depth in the upper $3-5 \mathrm{~km}$ of the water column (Fig. 3a). Both effects are due to the increased influence of Antarctic Bottom Water (AABW; $\epsilon_{\mathrm{Nd}} \approx-8$ ) in the western Pacific $[39,40]$. The very few $\epsilon_{\mathrm{Nd}}$ data for South Pacific seawater [38] mostly cluster between $\epsilon_{\mathrm{Nd}}=-4.5$ and -8.1 and thus suggest an even greater impact of $\mathrm{Nd}$ carried by Antarctic deep waters (Fig. 3b). In addition to deep water advective transport, the REE are transported vertically from surface waters to deep waters by exchange with settling particles [10]. As is commonly the case for the Atlantic and Indian oceans, most water column profiles in the Pacific show that surface waters $(<1 \mathrm{~km})$ are a source of $\mathrm{Nd}$ that is more radiogenic than in deeper waters (Fig. 3a,b).

Unfortunately, the seawater $\epsilon_{\mathrm{Nd}}$ data set for the Pacific Ocean is too small to constrain any regional variations in bottom water $\epsilon_{\mathrm{Nd}}$ as they 
relate to the potential eolian and hemipelagic sources mapped in Fig. 1a. However, the seawater data may be usefully supplemented with data from $\mathrm{Mn}$ nodules and crusts [24-26,41-43] provided that several limitations are kept in mind. First, Mn nodules and encrustations grow slowly such that even relatively thin layers represent considerable intervals of time $\left(\sim 10^{5}\right.$ to $>10^{6}$ years). Second, most of the Mn nodule and crust data compiled in Fig. 1b are undated. Third, "old" seawater Nd may be included in a given

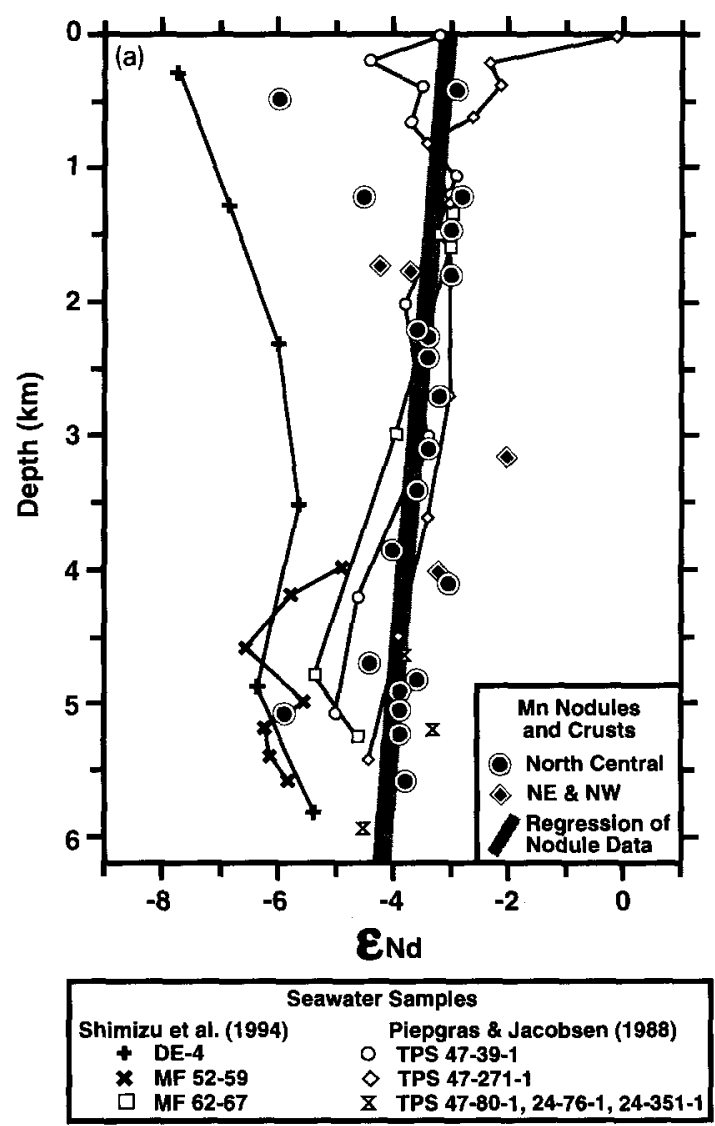

sample if the geochemistry of a given nodule was dominated by pore fluids derived from the breakdown of a hydrogenous component in the underlying sediments. Finally, some nodules have low enough REE concentrations that detrital silicate minerals within the nodule can distort the resulting $\epsilon_{\mathrm{Nd}}$ measurement [9]. Given these limitations, the $\mathrm{Mn}$ nodule and encrustation $\epsilon_{\mathrm{Nd}}$ data presented in Fig. $1 \mathrm{~b}$ are best viewed as a long-term late Cenozoic average.

Although one might reasonably expect deep

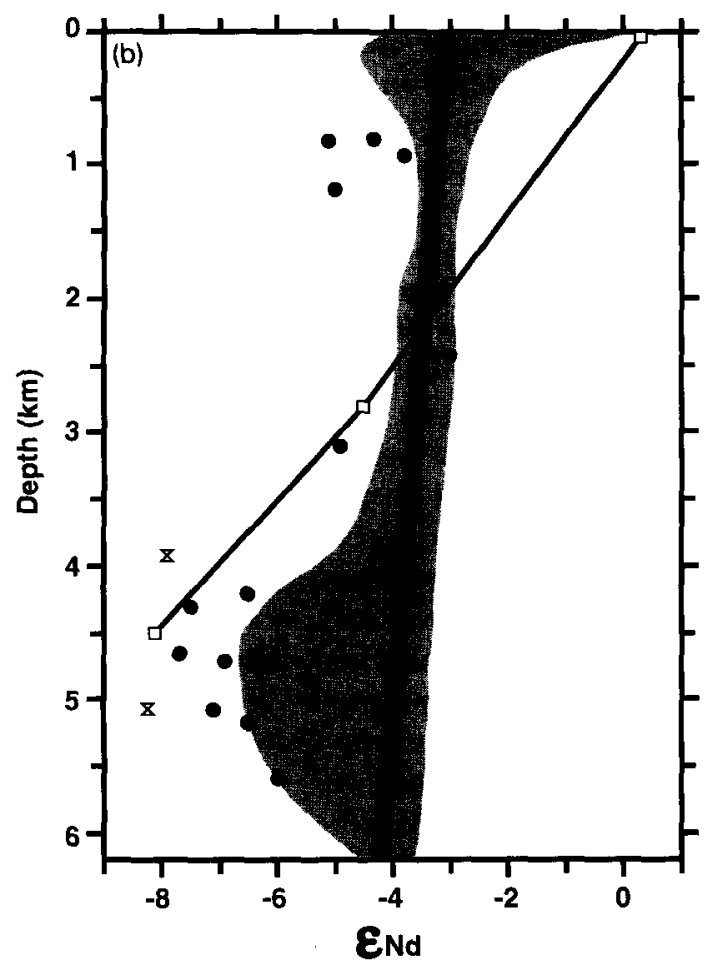

- Mn Nodules and Crusts Seawater Data: Piepgras and Wasserburg (1982) 口 Station $31 \quad x$ Stations $261 \& 292$

Fig. 3. (a) A plot of central North Pacific Mn nodule and crust $\epsilon_{\mathrm{Nd}}$ versus water depth shows that most samples (excepting 3 whose $\epsilon_{\mathrm{Nd}}<-4.5$ ) form a linear trend of decreasing $\epsilon_{\mathrm{Nd}}$ with depth. This trend exactly matches data from 3 water column profiles and 3 bottom water samples [39] down to a depth of 3-6 km, suggesting that the nodule data may be used as a reasonable proxy for modern oceanic bottom waters. Below $3 \mathrm{~km}$ the water column Nd tends to be less radiogenic than the nodule Nd, probably because the water column profiles were taken in the western North Pacific where the AABW has the greatest influence [39,40]. The unusual shape of profile DE-4 may reflect the input of eolian materials [18]. (b) A comparison between the North Pacific (shaded region plus linear regression) and available South Pacific data suggests that the South Pacific has lower $\epsilon_{\mathrm{Nd}}$, especially in deep waters but also perhaps in shallower waters. These less radiogenic $\epsilon_{\mathrm{Nd}}$ values reflect the increased influence of $A A B W$ in the South Pacific [38,42]. 
water circulation patterns and riverine REE inputs to have changed markedly over the course of the late Cenozoic, it turns out that the nodule data set as a whole is consistent with the modern seawater $\mathrm{Nd}$ data and oceanic circulation patterns. The best example of this is the comparison between the $\mathrm{Mn}$ nodule data from the central North Pacific sediment province and the North Pacific seawater data. When plotted as a function of depth, nearly all of the nodule data form a linear array becoming slightly less radiogenic with depth (Fig. 3a). Three of the four water column profiles covering most of the water column plus three bottom water samples plot remarkably close to the nodule-versus-depth regression line down to depths of between 3 and $5 \mathrm{~km}$. At depths greater than $4 \mathrm{~km}$, the seawater $\epsilon_{\mathrm{Nd}}$ data tend to become significantly less radiogenic than their nodule counterparts. This deviation from the linear trend probably reflects the fact that most of the water column profiles come from the western Pacific, where the influence of the $A A B W$ is stronger than in the central North Pacific, the source of the nodules [39]. The nodule data from the northwest and northeast marginal province do not form a good linear array (Fig. 3a), perhaps because these nodules come from areas of higher detrital sediment accumulation and thus are more likely to be contaminated by silicates dissolved during sample preparation. There is one highly unusual water column profile (Fig. 3a) that shows a $\epsilon_{\mathrm{Nd}^{-}}$-depth gradient opposite the norm: from -7.7 in surface waters to -6.0 in deep waters [18]. These data may indicate an input from eolian sources [18], the long-term impact of which is evaluated below.

The nodule and crust data from the South Pacific are also consistent with oceanographic data, but the paucity of seawater data makes detailed comparisons impossible. A total of three deep water data points from the central South Pacific (Fig. 1b) and from off the coast of Chile [38] yield $\epsilon_{\mathrm{Nd}}$ values of $\sim-8$ that clearly show the importance of Southern Ocean waters $\left(\epsilon_{\mathrm{Nd}} \approx\right.$ $-8)$. A number of encrustation data with $\epsilon_{\mathrm{Nd}}<$ -5 further supports a strong influence of $A A B W$ in the central South Pacific [42]. Overall, a plot of all South Pacific nodule and encrustation data versus depth (Fig. 3b) shows that all data are offset towards less radiogenic $\epsilon_{\mathrm{Nd}}$ relative to the North Pacific, which reflects the increased influence of Southern Ocean waters, and that the deepest encrustation samples are shifted to $\epsilon_{\mathrm{Nd}}$ values nearly as low as the three deep water samples. The surface water sample at Station 31 [38] suggests quite radiogenic $\mathrm{Nd}$ in shallow ( $>2$ $\mathrm{km}$ ) South Pacific waters, but more extensive sampling may have revealed a rapid shift to less radiogenic $\epsilon_{\mathrm{Nd}}$ in a manner analogous to North Pacific Site TPS 47-39-1 (Fig. 3a).

The previous discussion demonstrates that the $\mathrm{Mn}$ nodule and encrustation data yield $\epsilon_{\mathrm{Nd}}$ versus depth trends that are similar to modern seawater and regional $e_{\mathrm{Nd}}$ variations that reflect the expected influence of Antarctic deep waters on the southern and northwestern Pacific. It thus seems safe to use the $\mathrm{Mn}$ nodule and encrustation data along with the small seawater data set to estimate regional variations in bottom water $\epsilon_{\mathrm{Nd}}$. A map (Fig. 1b) and histogram (Fig. 2a) representation of the compiled bottom water data show no obvious regional $\epsilon_{\mathrm{Nd}}$ contrast between North Pacific bottom waters overlying the central and marginal sediment provinces. Instead, Fig. 3a suggests that much of the variability in the nodule data is controlled mainly by water depth and thus by the oceanographic factors that control the cycling of the REE within the Pacific Ocean, including the flow of $A A B W$ along the western Pacific. In fact, given the poor age constraints and slow nodule and crust growth rates, the remarkable oceanographic consistency of the nodule data set suggests a certain stability of the Pacific oceanic circulation and riverine weathering systems supplying isotopically distinctive $\mathrm{Nd}$ over the late Cenozoic. This implied constancy of Pacific seawater $\epsilon_{\mathrm{Nd}}$ over the late Cenozoic is also suggested by the work of Halliday et al. [8], which shows that the $\mathrm{Nd}$ isotopic composition of eastern Pacific seawater has remained constant over the past $16 \mathrm{Ma}$.

The North Pacific is ideally suited for evaluating the importance of silicate inputs of REE to the oceans because of the strong contrast between the central North Pacific province, with an exclusively eolian source of silicate minerals char- 
acterized by $\epsilon_{\mathrm{Nd}}=-10.2 \pm 0.5$, and the circumPacific province dominated by volcanic ash and hemipelagic sediments containing more radiogenic $\mathrm{Nd}\left(\epsilon_{\mathrm{Nd}}=-4.2 \pm 3.8\right)$. The addition of data from Pacific rim turbidites [29] yields an average $\epsilon_{\mathrm{Nd}}$ of $-2.3 \pm 4.9$ for ocean margin sediments. There are no direct isotopic data for the seafloor ashes mapped on Fig. 1a and b, but the $\epsilon_{\mathrm{Nd}}$ values of volcanic rocks from the Philippines and Japan generally range between -4 and +4 whereas volcanic rocks from the Marianas, Kuriles-Kamchatka, and Aleutian arcs range between +6 and +10 (Fig. 3c). The ash and hemipelagic components are potentially much more important than the eolian loess as sources of dissolved REE because volcanic ash is easily weathered on the seafloor (contributing, for example, significant amounts of $\mathrm{Sr}$ to sediment pore fluids as compared to no proven inputs from continental detritus $[44,45]$ ) and because hemipelagic silicate mass accumulation rates tend to be 2 to 3 orders of magnitude higher than dust accumulation rates in the pelagic realm [23] and thus are potentially a much larger source of $\mathrm{Nd}$ to the oceans (cf. Table 1).

Albarède and Goldstein [9] propose that the flux of $\mathrm{Nd}$ from eolian detrital sediments is so great that it imparts a local $\epsilon_{\mathrm{Nd}}$ signal to the vigorously circulating North Atlantic Deep Water (NADW). If a similarly large $\mathrm{Nd}$ flux were emanating from the North Pacific eolian silicate minerals, we would expect to see much of at least the central North Pacific deep waters (which move relatively sluggishly) tending towards $\epsilon_{\mathrm{Nd}}=-10$. However, as the $\epsilon_{\mathrm{Nd}}$ of North Pacific bottom waters averages around -4 (regression line of central North Pacific nodule data in Fig. 3a), it is obvious that any dissolved $\mathrm{Nd}$ derived from eolian Chinese loess has little effect on deep waters. Moreover, because shallow waters tend to show more radiogenic $\mathrm{Nd}$ than deep waters, the bulk of the data in Fig. 3a indicate that any contribution from eolian Chinese loess while it passes through the water column is also minor. It is worth noting here that we find no evidence for eolian inputs from the arid southwestern USA $\left(\epsilon_{\mathrm{Nd} \approx} \approx-6\right.$ $[34,36])$ to the northeastern Pacific between Hawaii and North America (Fig. 1a), nor for a systematic variation in Mn nodule $\epsilon_{\mathrm{Nd}}$ towards a minimum centered on the -6 datum east of Hawaii (Fig. 1b) that was proposed to result from the dust REE inputs [9].

The possibility that the marginal volcanic ash and hemipelagic sediments exude a large $\mathrm{Nd}$ flux is suggested by the close match between the $\epsilon_{\mathrm{Nd}}$ of the marginal sediments $(-2.3 \pm 4.9)$ and $\mathrm{Pa}$ cific seawater $(-3.5)$ (Fig. 2b). However, the fact that there is no contrast between the bottom water $\epsilon_{\mathrm{Nd}}$ data of the central and marginal sediment provinces suggests that any flux from the abundant, visible volcanic ash [46] and marginal sediments is also minor. In fact, the bottom waters overlying the rapidly accumulating, ash-rich sediments in the western North Pacific actually have lower $\epsilon_{\mathrm{Nd}}$ than the bottom waters overlying the slowly accumulating eolian loess of the central North Pacific, suggesting that any marginal sediment $\mathrm{Nd}$ flux is significantly smaller than the flux of $\mathrm{Nd}$ brought in by the AABW. Thus, although the volcanic ash and volcanogenic sediments are an attractive source of unradiogenic $\mathrm{Nd}$ for the Pacific [9], the data compiled here do not support their importance.

\section{Conclusions}

We thus conclude that detrital materials and volcanic ash carried to the deep oceans by eolian and hemiplegic processes contribute at best a minor proportion of the total REE transported to the Pacific Ocean by rivers and water masses moving in from the Southern and Indian oceans. These conclusions should be applicable to the oceans as a whole, since it is difficult to imagine that the chemistry of terrigenous detrital material is significantly different in other parts of the world, and there is evidence from both sediment and oceanographic studies from other oceans that supports our conclusions. For example, the $\epsilon_{\mathrm{Nd}}$ of eolian and voluminous riverine sediments entering the Indian Ocean from the Himalayas $[34,47]$ range between -17 and -12 ; in contrast, Indian Ocean seawater ranges between -10 and -7 [10]. If large fluxes of REEs from deep sea sedi- 
ments were a widespread process, elevated concentrations of REEs would be expected in nearbottom waters. However, elevated near-bottom REE concentrations are rare in Atlantic, Indian, and Pacific REE concentration profiles $[10,19,40]$. There are two seawater REE data sets that do, however, indicate an eolian contribution to seawater. Elderfield and Greaves [17] found elevated REE concentrations and a negative Eu anomaly in Atlantic surface waters off the coast of Africa, which suggest eolian inputs from the Sahara Desert. An eolian input to the northwestern Pacific is suggested at one site by $\epsilon_{\mathrm{Nd}}$ ranging from -7.7 in surface waters to -6.0 in bottom waters [18] (Fig. 3a). However, both of these cases are highly unusual, and the results of this study suggest that overall, eolian inputs are small compared to other REE sources.

The elimination of eolian, hemipelagic, and volcanic ash as significant sources of REE suggests that these sources do not have to be added to models of oceanic REE cycling such as that presented by Bertram and Elderfield [10]. However, these is still one potential particulate source of REE to seawater that needs to be considered: river water particulates. Sholkovitz has inferred a flux of REE from sediments and resuspended particles in the Amazon River estuary [3] and has experimentally shown that the introduction of riverine particulates to seawater results in a release of REE from the particles $[48,49]$. In the case of the Amazon, the release from these particles may increase the effective flux of $\mathrm{Nd}$ from 5 to $15 \%$ of the pre-estuary riverine flux. Thus, it is possible that the huge flux of particles carried by rivers (Table 1) results in a large increase in the flux of dissolved REE to the surface oceans. We speculate that the reason why the river particulates yield significant REE fluxes, whereas the eolian and hemipelagic sediments do not, rests with the freshly coagulated colloidal fraction in the riverine particulates. These fresh particles may either break down in seawater, release their REE to seawater, or dissolve during burial and give up their REE to pore waters expelled during the compaction of near-shore sediments. Sediments that are transported further out to sea to form the hemipelagic record have probably long since lost this labile colloidal component whereas eolian sediments may never have had it.

\section{Acknowledgments}

North Pacific surface sediment samples were provided by the core laboratories of Oregon State University, Scripps Institution of Oceanography, Hawaii Institute of Geophysics, and LamontDoherty Earth Observatory. This project was supported by NSF grants ATM 9221893, EAR 9205435, and EAR 9104877. We thank S.A. Hovan for help with the mineral extractions and $C$. Badgley for providing the two loess samples from Haojiatai, China. H. Elderfield, E.R. Sholkovitz, and an anonymous reviewer are thanked for providing helpful comments that significantly improved the manuscript.

\section{References}

[1] S.J. Goldstein and S.B. Jacobsen, REE in the Great Whale River estuary, northwest Quebec, Earth Planet. Sci. Lett. 88, 241-252, 1988.

[2] H. Elderfield, R. Upstill-Goddard and E.R. Sholkovitz, The rare earth elements in rivers, estuaries, and coastal seas and their significance to the composition of ocean waters, Geochim. Cosmochim. Acta 54, 971-991, 1990.

[3] E.R. Sholkovitz, The geochemistry of rare earth elements in the Amazon River estuary, Geochim. Cosmochim. Acta 57, 2181-2190, 1993.

[4] A. Michard, F. Albarède, G. Michard, J.F. Minster and J.L. Charlou, Rare-earth elements and uranium in hightemperature solutions from East Pacific Rise hydrothermal vent field $\left(13^{\circ} \mathrm{N}\right)$, Nature 303, 795-797, 1983.

[5] D.J. Piepgras and G.J. Wasserburg, Strontium and neodymium isotopes in hot springs on the East Pacific Rise and Guaymas Basin, Earth Planet. Sci. Lett. 72, 341-356, 1985.

[6] C.R. German, G.P. Klinkhammer, J.M. Edmond, A. Mitra and H. Elderfield, Hydrothermal scavenging of rareearth elements in the ocean, Nature 345, 516-518, 1990.

[7] A.M. Olivarez and R.M. Owen, REE/Fe variations in hydrothermal sediments: Implications for the REE content of seawater, Geochim. Cosmochim. Acta 53, 757 $762,1989$.

[8] A.N. Halliday, J.P. Davidson, P. Holden, R.M. Owen and A.M. Olivarez, Metalliferous sediments and the scavenging residence time of Nd near hydrothermal vents, Geophys. Res. Lett. 19, 761-764, 1992. 
[9] F. Albarède and S.L. Goldstein, World map of Nd isotopes in sea-floor ferromanganese deposits, Geology 20 , $761-763,1992$.

[10] C.J. Bertram and H. Elderfield, The geochemical balance of the rare earth elements and neodymium isotopes in the oceans, Geochim. Cosmochim. Acta 57, 1957-1986, 1993.

[11] C. Jeandel, Concentration and isotopic composition of $\mathrm{Nd}$ in the South Atlantic Ocean, Earth Planet. Sci. Lett. 117, 581-591, 1993.

[12] M.P. Bacon and R.F. Anderson, Distribution of thorium isotopes between dissolved and particulate forms in the deep sea, J. Geophys. Res. 87(C3), 2045-2056, 1982.

[13] M.J. Greaves, P.J. Statham and H. Elderfield, Rare earth element mobilization from marine atmospheric dust into seawater, Mar. Chem. 46, 255-260, 1994.

[14] C.D. Frost, R.K. O'Nions and S.L. Goldstein, Mass balance for $\mathrm{Nd}$ in the Mediterranean Sea, Chem. Geol. 55, 45-50, 1986.

[15] A.J. Spivack and G.J. Wasserburg, Neodymium isotopic composition of the Mediterranean outflow and the eastern North Atlantic, Geochim. Cosmochim. Acta 52, 2767-2773, 1988.

[16] M.J. Greaves, M. Rudnicki and H. Elderfield, Rare earth elements in the Mediterranean Sea and mixing in the Mediterranean outflow, Earth Planet. Sci. Lett. 103, 169-181, 1991.

[17] H. Elderfield and M.J. Greaves, The rare earth elements in seawater, Nature 296, 214-219, 1982.

[18] H. Shimizu, K. Tachikawa, A. Masuda and Y. Nozaki, Cerium and neodymium isotope ratios and REE patterns in seawater from the North Pacific Ocean, Geochim. Cosmochim. Acta 58, 323-333, 1994.

[19] H. Elderfield, The oceanic chemistry of the rare-earth elements, Philos. Trans. R. Soc. London, Ser. A 325, 105-126, 1988.

[20] C.R. German and H. Elderfield, Rare earth elements in the NW Indian Ocean, Geochim. Cosmochim. Acta 54, 1929-1940, 1990.

[21] E.R. Sholkovitz, D.J. Piepgras and S.B. Jacobsen, The pore water chemistry of rare earth elements in Buzzards Bay sediments, Geochim. Cosmochim. Acta 53, 2847$2856,1989$.

[22] S. Nakai, A.N. Halliday and D.K. Rea, Provenance of dust in the Pacific Ocean, Earth Planet. Sci. Lett. 119, 143-157, 1993.

[23] D.K. Rea, The paleoclimatic record provided by eolian deposition in the deep sea: The geologic history of wind, Rev. Geophys. 32, in press.

[24] R.K. O'Nions, S.R. Carter, R.S. Cohen, N.M. Evensen and P.J. Hamilton, $\mathrm{Pb}, \mathrm{Nd}$ and $\mathrm{Sr}$ isotopes in oceanic ferromanganese deposits and ocean floor basalts, Nature 273, 435-438, 1978.

[25] H. Elderfield, C.J. Hawkesworth, M.J. Greaves and S.E. Calvert, Rare earth element geochemistry of oceanic ferromanganese nodules and associated sediments, Geochim. Cosmochim. Acta 45, 513-528, 1981.
[26] D.B. Othman, W.M. White and J. Patchett, The geochemistry of marine sediments, island arc magma genesis, and crust-mantle recycling, Earth Planet. Sci. Lett. 94, 1-21, 1989.

[27] D.K. Rea and T.R. Janecek, Mass accumulation rates of the non-authigenic inorganic crystalline (eolian) component of deep sea sediments from the western Mid-Pacific Mountains, Deep Sea Drilling Project Site 463, Init. Rep. DSDP 62, 653-659, 1981.

[28] A.N. Halliday, G.A. Mahood, P. Holden, J.M. Metz, T.J. Dempster and J.P. Davidson, Evidence for long residence times of rhyolitic magma in the Long Valley magmatic system: the isotopic record of precaldera lavas of Glass Mountain, Earth Planet. Sci. Lett. 94, 274-290, 1989.

[29] S.M. McLennan, S.R. Taylor, M.T. McCulloch and J.B. Maynard, Geochemical and $\mathrm{Nd}-\mathrm{Sr}$ isotopic composition of deep-sea turbidites: Crustal evolution and plate tectonic associations, Geochim. Cosmochim. Acta 54, 20152050, 1990.

[30] M. Uematsu, R.A. Duce, J.M. Prospero, L. Chen, J.T. Merrill and R.L. McDonald, Transport of mineral aerosol from Asia over the North Pacific Ocean, J. Geophys. Res. 88, 5343-5352, 1983.

[31] G. Coudé-Gaussen, Le cycle des poussieres eoliennes desertiques actualles et la sedimentation des loess peridesertiques quarternaires, Bull. Elf-Aquitaine 8, 167-182, 1984.

[32] J.M. Prospero, Mineral-aerosol transport to the North Atlantic and North Pacific: The impact of African and Asian sources, in: The Long-Range Atmospheric Transport of Natural and Contaminant Substances, A.H. Knapp, ed., pp. 59-86, Kluwer, Dordrecht, 1990.

[33] S.R. Taylor, S. McLennan and M.T. McCulloch, Geochemistry of loess, continental crustal composition and crustal model ages, Geochim. Cosmochim. Acta 47, 1897-1905, 1983.

[34] S.L. Goldstein, R.K. O'Nions and P.J. Hamilton, A Sm$\mathrm{Nd}$ isotopic study of atmospheric dusts and particulates from major river systems, Earth Planet. Sci. Lett. 70, 221-236, 1984.

[35] J.T. Merrill, M. Uematsu and R. Bleck, Meteorological analysis of long range transport of mineral aerosols over the North Pacific, J. Geophys. Res. 94, 8584-8598, 1989.

[36] S.J. Goldstein and S.B. Jacobsen, $\mathrm{Nd}$ and $\mathrm{Sr}$ isotopic systematics of river water suspended material: implications for crustal evolution, Earth Planet. Sci. Lett. 87. 249-265, 1988.

[37] D.J. Piepgras, G.J. Wasserburg and E.J. Dasch, The isotopic composition of $\mathrm{Nd}$ in different ocean masses, Earth Planet. Sci. Lett. 45, 223-236, 1979.

[38] D.J. Piepgras and G.J. Wasserburg, Isotopic composition of neodymium in waters from the Drake Passage, Science 217, 207-214, 1982.

[39] D.J. Piepgras and S.B. Jacobsen, The isotopic composition of neodymium in the North Pacific, Geochim. Cosmochim. Acta 52, 1373-1381, 1988. 
[40] D.J. Piepgras and S.B. Jacobsen, The behavior of rare earth elements in seawater: Precise determination of variations in the North Pacific water column, Geochim. Cosmochim. Acta 56, 1851-1862, 1992.

[41] H. Amakawa, J. Ingri, A. Masuda and H. Shimizu, Isotopic compositions of $\mathrm{Ce}, \mathrm{Nd}$ and $\mathrm{Sr}$ in ferromanganese nodules from the Pacific and Atlantic Oceans, the Baltic and Barents Seas, and the Gulf of Bothnia, Earth Planet. Sci. Lett. 105, 554-565, 1991.

[42] A. Aplin, A. Michard and F. Albarède, ${ }^{143} \mathrm{Nd} /{ }^{144} \mathrm{Nd}$ in Pacific ferromanganese encrustations and nodules, Earth Planet. Sci. Lett. 81, 7-14, 1986.

[43] S.L. Goldstein and R.K. O'Nions, $\mathrm{Nd}$ and $\mathrm{Sr}$ isotopic relationships in pelagic clays and ferromanganese deposits, Nature 292, 324-327, 1981.

[44] H. Elderfield and J.M. Gieskes, $\mathrm{Sr}$ isotopes in interstitial waters of marine sediments from Deep Sea Drilling Project' cores, Nature 300, 493-497, 1982.

[45] J.M. Gieskes, H. Elderfield and M.R. Palmer, Strontium and its isotopic composition in interstitial waters of marine carbonate sediments, Earth Planet. Sci. Lett. 77, 229-235, 1986.

[46] J.P. Kennett, Marine tephrochronology, in: The Sea, 7 ,
The Oceanic Lithosphere, C. Emiliani, ed., pp. 13731436, Wiley, New York, 1981.

[47] A. Bouquillon, C. France-Lanord, A. Michard and J.-J. Tiercelin, Sedimentology and isotopic chemistry of the Bengal Fan sediments: the denudation of the Himalaya, Proc. ODP, Sci. Results 116, 43-58, 1990.

[48] E.R. Sholkovitz, Fractionation of rare earth elements in rivers and estuaries, Goldschmidt Conf. Abstr., 1994.

[49] E.R. Sholkovitz, The aquatic chemistry of rare earth elements in rivers and estuaries, Aquat. Geoch. submitted, 1994.

[50] R.A. Duce, P.S. Liss, J.T. Merrill, E.L. Atlas, P. BuatMenard, B.B. Hicks, J.M. Miller, J.M. Prospero, R. Arimoto, T.M. Church, W. Ellis, J.N. Galloway, L. Hansen, T.D. Jickells, A.H. Knap, K.H. Reinhardt, B. Schneider, A. Soudine, J.J. Tokos, S. Tsunogai, R. Wollast and M. Zhou, The atmospheric input of trace species to the world oceans, Global Biogeochem. Cycles 5, 193-259, 1990.

[51] E.K. Berner and R.A. Berner, The Global Water Cycle, 397 pp., Prentice-Hall, Englewood Cliffs, NJ, 1987.

[52] J.D. Milliman and R.H. Meade, World-wide delivery of river sediment to the oceans, J. Geol. 91, 1-21, 1983. 